\title{
DIE VERBOND - VAN OU TESTAMENT NA NUWE TESTAMENT
}

Prof. H. F. van Rooy

Die verbondsbegrip het in die Ou Testamentiese wetenskap weer 'n plek gekry op grond van die werk van Eichrodt' ${ }^{1}$ en die studie van ooreenkomste tussen die verbond in die Ou Testament en die buiteBybelse staatsverdrae, sedert die werk van Korošec, ${ }^{2}$ Mendenhall $^{3}$ en baie ander." Natuurlik bestaan hieroor nie eenstemmigheid nie, veral omdat oor die ouderdom van die verbondsgedagte in die $\mathrm{Ou}$ Testament nie eenstemmigheid bestaan onder geleerdes nie. Die studie van die verbond in die Nuwe Testament het egter nie naastenby dieselfde aandag gekry nie - iets wat miskien as een van die redes vir die ontkenning van die waarde van die verbond vir Nuwe-Testamentiese gelowiges beskou kan word. In hierdie studie word drie sake aangeraak, nl. die terminologie vir verbond in die Ou en Nuwe Testament, die agtergrond vir en belangrikste vorme van die verbond in die $\mathrm{Ou}$ Testament en enkele opmerkings oor die verbond in die Nuwe Testament.

\section{TERMINOLOGIE.}

\subsection{Berith.}

Dat berith die algemene term vir verbond in die $\mathrm{Ou}$ Testament is, is goed bekend. Dat die woord egter 'n wye semantiese veld het, word meermale nie in gedagte gehou nie. Oor die presiese afbakening van die veld bestaan daar ook meningsverskil, soos gesien kan word in die standaard-artikels van Weinfeld ${ }^{5}$ en Kutsch. ${ }^{6}$ Kutsch, wat geweldig baie navorsing oor hierdie woord gedoen het, sowel wat etimologie as gebruik betref, ${ }^{7}$ is baie uitgesproke daaroor dat die tradisionele siening dat berith op 'n verhouding tussen verskillende partye dui - soos God en sy volk - totaal verkeerd is. Die woord kan volgens hom net dui op een of ander verpligting. ${ }^{8}$ So sal in wat as die verbond van God met Abraham bekend staan die begrip berith alleen kan dui op God se selfverpligting teenoor Abraham, sonder dat dit dui op die verhouding tussen hulle. Die verbond by Sinai weer is eintlik bloot die verpligtinge wat God op sy volk gelê het. Die verhoudingsfeer word daardeur uit die oog verloor. Weinfeld daarenteen gee wel toe dat die begrip aanvanklik bloot op verpligtings kon gedui het, maar dat dit algaande wel gebruik is vir die verbondsgedagte, vir die besondere verhouding tussen twee partye. ${ }^{9}$ Op hierdie saak is elders volledig ingegaan, met die gevolgtrekking dat die semantiese veld van berith wyer is as net verpligting, om ook die elemente van seën en vloek en die besondere verhouding, spesifiek tussen God en sy volk, in te sluit. ${ }^{10}$ Hierdie verhoudingselement is egter nie oral teenwoordig waar die begrip aangetref word nie, sodat daar wel versigtig met die begrip omgegaan moet word.

Daar moet ook onthou word dat die begrip nie net vir die verhouding tussen God en sy volk gebruik word nie. Dit is inderdaad 
waarskynlik dat berith - soos die begrip vader - uit die menslike lewe en verhoudings spruit en daaruit oorgeneem is ter uitdrukking van die verhouding tussen God en sy volk. ${ }^{11}$

\subsection{Diatheke}

Diatheke word in die LXX gebruik as die mees algemene vertaling van berith. Daar kan 'n lyn gevolg word van daar af tot by die vertaling van diatheke met testament in die ou Afrikaanse vertaling van die Nuwe Testament. Populêr word dit gewoonlik so gestel dat diatheke in Grieks eintlik op 'n testament dui, iets wat alleen van krag word na die dood van die testamentmaker.

Die eintlike woord vir 'n verdrag is egter suntheke. Die vertalers van die LXX wou dit egter nie gebruik nie, omdat dit eerder dui op 'n verdrag of ooreenkoms tussen gelyke partye, met wedersydse verpligtinge. Hierdie vereenvoudigde standpunt word bv. aangetref in die standaardartikel van Guhrt. ${ }^{12}$. Sowel Behm ${ }^{13}$ as Arndt en Gingrich $^{14}$ wys egter daarop dat daar een geval is in Klassieke Grieks waar die woord wel op 'n ooreenkoms of kontrak dui. Arndt en Gingrich ${ }^{15}$ oordeel egter dat dit nie ' $n$ invloed op die Nuwe Testament gebruik gehad het nie. Behm oordeel wel dat diatheke 'n wyer veld gehad het, in sowel Klassieke Grieks as in die LXX as net testament.13 Behm is van mening dat die betekenis van diatheke wissel tussen "covenant" en "disposition" in die Nuwe Testament. ${ }^{17}$

Dit is wel merkwaardig dat nie een van die gemelde standaardartikels blyke gee daarvan dat kennis geneem is van die studie van Burton oor die term in sy kommentaar op Galasiërs nie. ${ }^{18} \mathrm{Hy}$ onderskei in Klassieke Grieks benewens die gebruik van diatheke vir 'n testament 'n ander gebruik: "An arrangement or agreement between two parties in which one accepts what the other proposes or stipulates; somewhat more one-sided than a diatheke". ${ }^{19}$ Wat die LXX betref, moet die betekenis van diatheke grotendeels bepaal word deur die betekenis van berith ${ }^{20}$. Diatheke is waarskynlik gekies weens die Klassieke agtergrond waarvolgens dit wel op 'n ooreenkoms kan dui en die feit dat suntheke 'n ooreenkoms tussen gelyke partye aandui, wat nie pas by die berith tussen God en sy volk nie.

Hierdie gebruik van diatheke word gevolg deur die apokriewe en dikwels deur Philo. ${ }^{21}$ In die latere nie-Joodse Grieks word diatheke wel deurgaans vir 'n testament gebruik.22 Burton se opmerking as samevatting oor die gebruik van die term voor die Nuwe Testament, bly baie belangrik: "It is of prime importance to observe that in the diatheke (berith) between God and men, so often spoken of in OT, the initiative is with God, and the element of promise or command is prominent; but it still remains essentially a covenant, not a testament. In their emphasis on the former fact some modern writers seem to lose sight of the latter." ${ }^{23}$ Dit word deur Behm bevestig, wat verklaar dat die gedagte aan die verbond as 'n testamentêre beskikking vreemd aan die Ou Testament is. ${ }^{24}$

Dit is dus niks meer as logies dat die gebruik van diatheke in die Nuwe Testament teen hierdie agtergrond benader moet word, soos gedoen sal word in die laaste afdeling van hierdie studie. 


\subsection{Berith/Diatheke-testamentum/foedus, pactum - testament/ verbond.}

Soos reeds gemeld, kan die vertaling van diatheke meermale met testament in die ou Afrikaanse vertaling van die Nuwe Testament verklaar word langs 'n lyn wat van diatheke af loop, veral deur die Latynse vertalings van die Ou Testament. Die oudste Latynse vertaling van die Ou Testament, die Vetus Latina (of Itala, is nie 'n vertaling uit die Hebreeus nie, maar 'n vertaling van die LXX. Die Griekse diatheke word in die Ou Testament feitlik deurgaans vertaal met testamentum en in die Nuwe Testament, interessant genoeg, met instrumentum. Die Vulgaat, wat uit 'n later tyd dateer, vertaal daarenteen meer uit die Hebreeus wat die Ou Testament betref. berith word vertaal met of foedus of pactum. In die Nuwe Testament weer word die Griekse diatheke met testamentum weergegee - en die lyn daarvandaan na testament in die ou Afrikaanse vertaling is duidelik sigbaar.

\section{DIE VERBOND IN DIE OU TESTAMENT.}

Die feit dat die verbond in die Ou Testament nie 'n eenvormige beeld vertoon nie, word dikwels uit die oog verloor. Vereenvoudigd word dit dikwels so verstaan dat God die inisiatief neem, die verbond sluit, sekere verpligtinge op Homself neem (soos om sy volk te verlos) en sekere verpligtinge op die mens lê (soos om na God se Woord te luister). Op hierdie wyse word daar egter nêrens oor "die verbond" in die Ou Testament gehandel nie. Dit word meer konkreet gedoen, deurdat God telkens 'n verbond sluit met 'n spesifieke persoon of groep persone. In die konkrete gevalle is daar telkens ook net van een stel verpligtinge sprake, nl. of dit wat God op Homself neem, of dit wat Hy op die mens lê.

Daar kan dus in die Ou Testament twee soorte verbonde onderskei word wat die verhouding tussen God en sy volk betref. Wat die verhoudings (verdrae) tussen mense betref, wat ook deur die woord berith aangedui word, kan daar inderdaad vier tipes onderskei word, nl. susereiniteitsverdrae (waarin 'n meerdere 'n mindere verpligtinge oplê), pariteitsverdrae, beskermheerverdrae (waarin die meerdere verpligtinge op homself lê tot voordeel van die mindere) en verdrae waar ' $n$ meerdere 'n verdrag sluit tussen twee kleiner partye. ${ }^{25}$ Die twee soorte verbondsluitings wat in die Ou Testament voorkom, vertoon ooreenkomste met die eerste en derde van die vier soorte hierbo genoem, susereiniteits- (of vasal-) verdrae en beskermheerverdrae.

In die afgelope dertig jaar is daar heelwat aandag gegee aan die formele ooreenkomste tussen die verbond in die Ou Testament en die buite-Bybelse staatsverdrae, veral die Hetitiese en Assiriese vasalverdrae. ${ }^{28}$ Ook hier moet daar egter fyn onderskei word, om die saak nie te forseer nie. Hierdie soort van formele ooreenkomste moet nie oral gesoek word waar daar in die Ou Testament van die verbond sprake is nie. Die ooreenkomste tussen die buite-Bybelse verdrae en die verbond in die Ou Testament is beperk tot die gevalle waar God die mens (volk) verpligtinge oplê, soos in die Sinaitiese verbond of in Deuteronomium, wat duidelik 'n verbondsboek is. 
Die feit dat in die verbond met Abraham (en Dawid) daar ook 'n meerdere en mindere party is, moet 'n mens nie mislei om daar ook sulke ooreenkomste te soek nie.

Wat die vasalverdrae en die verbond betref, is daar inderdaad belangrike ooreenkomste, wat nogal lig op die verbond by Sinaĩ en in Deuteronomium werp. Dit raak veral die opset, die struktuur van die verbond, waaroor veral in Deuteronomium baie gesê kan word. ${ }^{27}$ Duidelik moet gesien word dat die meerdere (God) na die mindere kom (die volk). Hy neem die inisiatief en lê sy volk sekere verpligtinge op, nie as harde eise nie, maar as iets wat volg op 'n sekere bewys van genade wat die verbondsluiting voorafgegaan het. So rus die verbond dus op die genade van God. Eers bv. het $\mathrm{Hy}$ sy volk verlos uit Egipte en dan kom die eis tot gehoorsaamheid, soos in Ex. 19 gesien kan word. Iets wat ook in die verdrae opgemerk kan word, is dat dit ' $n$ kollektiewe element het. Dit kan bv. duidelik in die Sefire-verdrae gesien word (IA 1-6 en IB 1-6) dat nie net die ondergeskikte koning nie, maar ook sy nageslag en sy land met sy adel en inwoners ingesluit was daarby. ${ }^{28}$ Dit kan ook in verskeie van die Hetitiese verdrae gesien word. ${ }^{20}$ en in die vasalverdrae van Esarhaddon. ${ }^{30}$ Dat die verbond by Sinai en Deuteronomium dieselfde element bevat, is baie duidelik. In Deuteronomium 29 maak Moses dit duidelik dat die verbond met die volk is, dat die Here hulle God sal wees en hulle sy volk.

Verder moet ook daarop gelet word dat die staatsverdrae nie onvoorwaardelik was nie. Die ontvanger daarvan was verplig tot gehoorsaamheid aan sy heer - en 'n gebrek aan gehoorsaamheid sou duidelik lei tot strafmaatreëls. Gehoorsaamheid was dus nie 'n vereiste vir die oprigting van die verdrag nie, maar iets wat daaruit voortgevloei het. In die Hetitiese verdrae word duidelik gestel dat gehoorsaamheid beloon en ongehoorsaamheid gestraf sou word. Ongehoorsaamheid is verdragsverbreking en die verdragsverbreker is vervloek. In die latere Assiriese verdrae word daar nie eers van seëninge melding gemaak nie. Daar word slegs vloeke - in besonderhede uitgewerk, soos in Deut. 27 en 28 - uitgespreek oor die verdragsverbreker. Hierdie saak werp ook lig op die vervloeking in die verbond in die Ou Testament, soos spesifiek in Deut. 27 en 28, of in die tweede en derde gebod. God het van sy volk gehoorsaamheid vereis, nie as voorwaarde vir die oprigting van die verbond nie, maar as resultaat daarvan. Dit maak egter nie die gehoorsaamheid van minder belang nie, maar eintlik van meer belang. Wat die volk self betref, kan daar dus nie 'n onvoorwaardelike beroep op die verbond gewees het, wanneer hulle hulle verpligtinge nie nagekom het nie. So kon die volk die verbond verbreek en onder God se toorn kom, soos telkens gebeur het.

Die verbond met Abraham vertoon egter 'n ander patroon. Daar kan inderdaad ook daarvoor 'n buite-Bybelse parallel aangetoon word, soos Weinfeld gedoen het. ${ }^{31}$ Hy het 'n hele aantal strukturele ooreenkomste aangetoon tussen die verbond met Abraham en die sogenaamde koninklike toekenning (royal grant), wat uit die geskiedenis van Mesopotamië bekend is. In hierdie koninklike geskenk: 
neem die koning, die groter party, 'n verpligting op homself en word die vloek gerig teen die een wat die regte van die onderdaan benadeel. Daar is wel 'n formele ooreenkoms in die struktuur van staatsverdrae en so 'n koninklike toesegging, maar tog 'n belangrike inhoudelike verskil: "In other words, the 'grant' serves mainly to protect the rights of the servant, while the treaty serves to protect the rights of the master." 32

Die opset van die verbond met Abraham kan inderdaad met so 'n koninklike toesegging vergelyk word, ook in sulke konkrete sake soos die belofte van 'n land en nageslag vir Abraham. Hierdie onderskeid tussen die twee verbondsvorme in die Ou Testament word deur heelwat skrywers aangedui, ${ }^{3:}$ maar daar moet nie 'n wig tussen die twee soorte ingedryf word al sou hulle teenoor mekaar staan nie. Daar moet nie gevra word watter een van die twee is gesaghebbend (en watter nie?). Albei bly uitdrukkings van die verhouding tussen God en sy volk. Wat wel waar is en wat veral in die tyd van Jeremia gesien kan word, is dat daar deur die interpretasie wat die volk aan die verbond geheg het, 'n spanning gekom het tussen die "aanhangers" van die twee verbondstipes. Dit was 'n spanning tussen hulle wat alleen maar wou vashou aan God se selfverpligting en genade en hulle wat, soos Jeremia, ook die klem wou laat val op die verpligtinge wat God die volk opgelê het en wat alleen tot eie ondergang nagelaat kan word.

Wat die selfverpligting van God en die Abrahamitiese verbond betref, het Lion-Cachet 7 beloftes onderskei, ${ }^{34}$ waarvan die land- en nageslagsbelofte die belangrikste is. Uit laasgenoemde vloei ook voort dat uit die nageslag konings sal voorkom, waarop die verbond met Dawid weer teruggaan. ${ }^{30}$ Ook is die gemeenskapsbelofte baie belangrik, deurdat dit duidelik gestel word dat ook Abraham se nageslag hierby betrokke is. ${ }^{36}$

Al wat van Abraham verwag word is lojaliteit en die onderhouding van die verbondsteken. ${ }^{37}$ Hierdie verbond beklemtoon baie sterk God se genade, sy inisiatief en sy trou.

In die voortgang van die Ou Testamentiese openbaring moet dit gestel word dat die verbond met Abraham die primêre plek inneem. Dit gaan die verbond by Sinai vooraf. Wat die ouderdom van die verbondsgedagte in die Ou Testament betref, word dit meermale gestel dat dit eintlik 'n latere ontwikkeling in die Ou Testament is. Dit dateer al sedert Wellhausen, ${ }^{38}$ maar is redelik onlangs sterk gestel deur L. Perlitt. ${ }^{39}$ Die vergelyking met buite-Bybelse gegewens - wat normaalweg as onwettig beskou word deur voorstanders van die gedagte dat die verbond nie 'n ou tradisie in die Bybel is nie ${ }^{40}-$ verskaf egter vergelykende gegewens uit vroeë tye, tot selfs vroeg in die tweede millennium v.C. in die geval van die koninklike toeseg. ging. Die $\mathrm{Ou}$ Testament self is uitgesproke daaroor dat die verbond met Abraham die grondslag vir die bestaan van die latere Israel is.

Die verbond met Abraham en die verbond by Sinai mag ook nie teenoor mekaar afgespeel word nie. Ook hieroor het Lion-Cachet baie duidelik gegewens verskaf. ${ }^{41}$ Alhoewel daar die strukturele verskille is waarop daar reeds gewys is, is daar ook 'n baie duidelike 
kontinuīteit van die Abrahamitiese verbond na die Sinaïtiese verbond, In ' $n$ besondere sin kan die stelling gemaak word dat die Abrahamitiese verbond ' $n$ eerste vervulling vind met die intog in en oorname van die beloofde land..42 Dit is natuurlik nie daarmee afgehandel nie, maar tog het dit daar reeds in vervulling begin gaan. Die Sinaïtiese verbond en veral die hernuwing daarvan in Deuteronomium wil die lewe van die volk in die beloofde land reël. Op die wyse is dit iets van 'n nadere bepaling by die Abrahamitiese verbond.

Die Abrahamitiese verbond is dus primêr en bly voortbestaan. Dit dra ook 'n onvoorwaardelike karakter, met slegs die eis tot lojaliteit daarby. Wanneer die beloftes, die selfverpligting van God, in vervulling begin gaan, word hierdie laaste saak, die lojaliteit aan God verskuldig, nader uitgewerk. In hierdie nadere uitwerking word daar wel duidelik voorwaardes gestel aan die volk, nie vir die oprigting van die verbond nie, maar vir die voortbestaan daarvan. Die volk kan hom nie eensydig op die genade of selfverpligting van God beroep, sonder om sy eie verpligtinge na te kom nie. Deur die verbondsluiting word die besondere band tussen God en die volk gelê, maar dit mag nie gesien word as 'n meganiese band wat sou bly voortbestaan ongeag die optrede van die volk nie. In Deut. $30: 11-20$ word dit duidelik gestel dat die onderhouding van die verbond op die lewe sal uitloop en die verbreking daarvan op die dood.43 Seën en vloek vorm albei deel van die opset van die verbond, soos gesien kan word in Deut. 27 en 28 , wat 'n duidelike plek het in die verbondsopset van Deuteronomium. ${ }^{44}$

Die verdere geskiedenis van Israel kan ook in die lig hiervan beoordeel word. So wys die rigtertydperk duidelik dat verbondsverbreking gestraf is. Die volharding in verbondsverbreking het uitgeloop op eers die ondergang van die Noordelike ryk en later op die ondergang van die Suidelike ryk.

In die verdere verloop van die verbond in die Ou Testament moet daar aan nog twee kardinale momente aandag gegee word. Die eerste is die verbond met Dawid. Die ooreenkoms in die opset van die Dawidiese en Abrahamitiese verbonde is voor die hand liggend. ${ }^{45}$ In werklikheid kan gestel word dat die Dawidiese verbond ook 'n nadere presisering van die Abrahamitiese verbond is. Veral een van die beloftes aan Abraham word hier verder uitgebou, nl. die koningsbelofte. ${ }^{40}$ Die feit dat dit dus eintlik ook 'n beskermheersverdragsvorm vertoon, is in die lig hiervan nie vreemd nie en bring dit ook nie in stryd met die voorwaardelike aspek van die Sinaïtiese verbond nie.

Die tweede belangrike moment waaraan aandag gegee moet word is die verbond in die tyd van Jeremia. Dat daar in sy tyd 'n spanning gekom het weens die verskillende verbondsinterpretasies, kan maklik aangetoon word. In Jeremia se tempelrede in Jer. 7 word beskryf dat die volk vertrou het (op die verbond) terwyl hulle die bepalinge nie nagekom het nie en goddeloos gelewe het. In Jeremia 11 word dit weer beklemtoon dat die verbreker van die verbond vervloek is. ${ }^{47}$ Dit blyk inderdaad uit die hele geskiedenis van die volk dat dit voortdurend die geval was dat God se oordeel die volk getref het wanneer hulle d'e verbond verbreek het. ${ }^{48}$ Die spanning was dat die volk on- 
der leiding van valse profete God se beloftes aangegryp het sonder om hulle verpligtinge na te kom. Dit is alleen maar ' $n$ doodloopstraat.

Juis in hierdie tyd van spanning en ondergang kom daar egter wat 'n mens die hoogtepunt van die verkondiging oor die verbond in die Ou Testament kan noem, die nuwe verbond. Die spanning wat in die interpretasie van die verbond gekom het, word daardeur opgelos. Freedman stel dat dit daardeur geskied dat in die nuwe verbond wedersydse verpligtinge is, ${ }^{19}$ wat dus daarop neerkom dat die twee verbondsvorme ineenvloei. Tog wil dit voorkom asof die gegewens van Jer. $31: 31$ vv. nie so 'n konklusie ondersteun nie. In vers 32 word duidelik gestel dat hierdie nuwe verbond kom in die plek van die verbond wat met die uittog uit Egipte gesluit is. Die nuwe verbond vervang dus eintlik die ou nadere uitwerking van die Abrahamitiese verbond, met 'n nuwe uitwerking, wat meer klem op die inwendige sy van die verbond lê. Die probleem by Israel was juis meermale ' $n$ veruitwendiging van die verbond, met fatale gevolge. Waaraan egter baie sterk vasgehou moet word, is dat die nuwe verbond die gemeenskaplike element van beide die Abrahamitiese en Sinaïtiese verbond voortsit. Jer. $31: 33$ stel dit bo alle twyfel. In die nuwe verbond geld steeds: "Ek sal hulle God wees en hulle sal my volk wees." Die nuwe verbond rus steeds op die genade van God en dit stel steeds voorwaardes wat nagekom moet word. Die nakoming sal egter van harte wees omdat die volk die wet op hulle harte sal dra. Dit ontvang hier besondere klem, en tog is dit nie nuut nie. Ook in die ou verbond was dit die bedoeling. Dit wat God van die volk gevra het by Sinai is nie ver van hulle nie, maar in hulle mond en in hulle hart (Deut. $30: 14$ ).

Met hierdie hoogtepunt eindig die verloop van die verbond in die Ou Testament onvolledig. Dit wys vooruit na die tyd van die nuwe verbond wat moes kom.

\section{VERBOND IN DIE NUWE TESTAMENT.}

Die begrip diatheke kom in die Nuwe Testament slegs 33 keer voor, wat vergelyk kan word met die 287 keer wat berith in die Ou Testament voorkom. Die begrip verbond kom dus baie meer in die $\mathrm{Ou}$ Testament voor, alhoewel in gedagte gehou moet word dat daar heelwat gevalle in die Ou Testament is waar berith gebruik word as aanduiding van verdrae tussen mense en ongeveer 40 gevalle waar dit voorkom in die uitdrukking aron haberith (die verbondsark). Tog kom die begrip as aanduiding van 'n verhouding tussen God en die mens seker ses keer soveel in die Ou Testament as die Nuwe Testament voor, terwyl die begrip die koninkryk van God baie algemeen in die Nuwe Testament is, veral in die sinoptiese evangelies. Die twee begrippe moet nie teen mekaar afgespeel word nie ${ }^{50}$ en dit gaan ook nie hier oor die kwessie van 'n sentrale lyn in die Bybel nie. Die verband tussen die twee begrippe moet egter raakgesien word. Die verbond funksioneer nie so baie in die Nuwe Testament nie, omdat baie sake wat in die Ou Testament onder die noemer van die verbond tuisgebring is, in die Nuwe Testament onder die koninkryk 
tuisgebring is. ${ }^{51}$ Miskien kan die aanvanklike klem wat die koninkryksgedagte in die sinoptiese evangelies kry teenoor die minder direkte klem in die res van die Nuwe Testament daaraan toegeskryf word dat Jesus self aangesluit het - soos ook Johannes die doper by die (dikwels verkeerde) koninkryksverwagting onder die Jode.

Van die 33 keer wat die woord diatheke in die Nuwe Testament voorkom, is die verspreiding soos volg: 17 in Hebreërs, 9 by Paulus, 4 in die sinoptiese evangelies, 2 in Handelinge en 1 in Openbaring. Sewe hiervan is direkte aanhalings uit die Ou Testament, nl. vyf aanhalings uit Jer. $31: 31$ vv. in Hebr. $8: 8,9(2 x)$ \& 10 en $10: 6$, een aanhaling uit Ex $24: 8$ in Hebr. $9: 20$ en een uit Jes. $59: 21$ in Rom. 11:27. In die oorgrote meerderheid van die res kan ten minste 'n sinspeling op die verbond in die Ou Testament aangedui word, sodat dit duidelik word dat diatheke in die Nuwe Testament grotendeels teen die agtergrond van berith in die Ou Testament verstaan moet word. Daar is slegs enkele uitsonderings hierop, soos die twee gevalle in Hebr. $9: 16$ en 17, waar duidelik in die argument op die testamentgedagte gebou word, dus met, ter wille van die argument, 'n sprong van diathe$k e$ as verbond teen die agtergrond van die Ou Testament na diathe$k e$ as die meer algemene Hellenistiese testament. Van die ander gevalle waar diatheke voorkom, is almal teen die agtergrond van die Ou Testament te verstaan, met miskien Gal. 3:15 en 17 as uitsondering. Guhrt ${ }^{52}$ en Behm $^{53}$ wil albei die twee verse teen die testamentagtergrond verstaan, maar Burto ${ }^{54}$ het 'n lang en grotendeels oortuigende argumentasie daarteen.

Die hele saak van die verbond in die Nuwe Testament het tans indringende studie nodig. Hier kan alleen volstaan word met ' $n$ aantal opmerkings oor die band tussen Ou Testament en Nuwe Testament en die lyn wat getrek kan word. Wat die instelling van die Nagmaal betref en die verwysing na die (Kaine) diatheke in verbinding met die beker wyn en die bloed, word daar in die sinoptiese evangelies (Matt. 26:28, Mark $14: 24$ en Luk. 22:20) en in I Kor. $11: 25$ op verskillende wyses sinspeling gemaak op sowel Jer. $31: 31$ vv. (die nuwe verbond) en Ex. $24: 8$ (die bloed van die verbond). Soos die ou verbond by Sinai beseël is met die bloed van offerdiere word die nuwe verbond beseël met die bloed van Christus. Hier word dus van nuwe verbond gepraat in die sin van die nuwe bedeling van die Abrahamitiese verbond, soos Jer. $31: 31 \mathrm{vv}$. ook na die nuwe verbond verwys. Dit geld inderdaad van al die gevalle waar daar na 'n nuwe verbond verwys word dat dit nêrens in teenstelling met die Abrahamitiese verbond gebruik word nie, maar deurgaans in die sin van Jer. $31: 31$. Die nuwe verbond wat Christus gebring het, is dus bloot 'n nuwe bedeling van die primêre verbond, die verbond met Abraham. Daar word wel soms na die Abrahamitiese verbond verwys (bv. Luk. $1: 72$ en Hand. $3: 25$ en $7: 8$ ), maar daar word meesal die klem geplaas op God se durende beloftes.

In die vergelyking wat in Hebreërs gemaak word tussen die ou en die nuwe bedeling, speel die saak van die nuwe verbond 'n belangrike rol, soos ook gesien kan word uit die aanhaling van Jer. $31: 31 \mathrm{vv}$. in Heb. $8: 8 \mathrm{vv}$. Die grond vir die nuwe verbond is dui- 
delik die soenverdienste van Christus (Heb. $10: 9,10,12,14$ ). Hierop volg die werk van die Gees om die gelowiges ook rein te laat lewe, met God se wet op hulle harte geskryf (Heb. 10:14-16). Die patroon van voorop God se genade (indikatief) en dan die gelowiges se verpligtinge (imperatief) bly voortbestaan. Ook die seën en die vloek bly staan. Hy wat die Seun van God verag, sal sy straf ontvang en hy wat volhard, die seën. Die nuwe verbond spreek van 'n nuwe bedeling, maar die werklike aard van die verbond het dieselfde gebly. Verbreking van die verbond deur ongehoorsaamheid is net so ' $n$ doodsweg in die Nuwe Testament as in die Ou Testament.

Ter afsluiting ' $n$ paar opmerkings oor twee sake wat tans onder diskussie is. Eerstens is daar die vraag of die verbond in die Nuwe Testament ook die gemeenskapselement het soos in die Ou Testament. Daar is dit wel duidelik dat die verbond die volk, die gemeenskap, geraak het. Dit is reeds duidelik by die verbond met Abraham en daardie verbond met sy beloftes word nie in die Nuwe Testament opgehef nie. Reeds aan Abraham is belowe dat die beloftes van die verbond met hom al die geslagte van die aarde insluit. Vir Abraham was dit 'n verbond met hom en sy kinders. In die Nuwe Testament geld dit onvervals, soos Petrus dit baie duidelik uitgespel het in Hand. 2:39 (net nadat die mense op Pinkster beveel is om hulle te laat doop): Want die belofte kom julle toe en julle kinders en almal wat daar ver is, die wat die Here onse God na Hom toe sal roep. Wie dit ontken, maak 'n teenstelling tussen $\mathrm{Ou}$ en Nuwe Testament.

Die tweede saak hang hiermee saam, nl, die kwessie van die kinderdoop. Dat die verbond met Abraham ook met sy kinders was, is bo alle twyfel. Dat die kinders daar ook die teken van die verbond ontvang het, het geen bewys nodig nie. Om dus te redeneer dat die Nuwe Testament hier van die Ou Testament verskil, plaas die bewyslas op hulle wat die kinderdoop ontken - en om te wys op Jesus of mense wat groot gedoop is, is nie genoeg nie. Dat die doop in die plek van die besnydenis gekom het, volg uit Kol. 2:11 en 12 . Die argumentasie daarvoor deur Hendriksen is heeltemal oortuigend..$^{.5}$

Indien hierdie studie verder kan stimuleer tot eksegetiese bestudering van die Nuwe-Testamentiese gegewens oor die verbond, was die voorbereiding meer as die moeite werd.

Gelewer voor GTV Pretoria Februarie 1983.

\section{VERWYSINGS:}

1. Sy Teologie van die Ou Testament is in 1933 die eerste keer gepubliseer in Duits.

2. Korosec, V. 1931. Hethitische Staatsverträge. Leipzig.

3. Mendenhall, G. E. 1954. "Ancient Oriental a ndBiblical Law", The Biblical Archaeologist $17: 26-46 ; 1954$. "Covenant forms in Israelite tradition." The Biblical Archaeologist $17: 50-76$. 
4. Vir 'n omvattende oorsig, vgl. McCarthy, D. J. 1973, Old Testament Covenant. A survey of current opinions. Oxford.

5. Weinfeld, M. 1972 bryt (In Theologisches Wörterbuch zum Alten Testament I 6/7: 781-808.)

6. Kuisch, E. 1971. "Berit Verpflichtung" (In Theologisches Handwörterbuch zum Alten Testament 1 : 339-352).

7. Vir 'n aantal van sy artikels in een bundel, vgl. Kutsch, E. 1973. Verheissung und Gesetz. Berlyn.

8. Ibid. viii, 95-96, 102-121 en 134-153.

9. Op. cit., 784-785.

10. Van Rooy, H. F. 1982 bryt in Jeremiah 11. OTWSA 24 (1981): 93-102.

11. McCarthy, op. cit., 65

12. Guhrt, J. 1975. "Covenant" (In: C. Brown ed. Dictionary of New Testament Theology $1: 365)$.

13. Bchm, J. 1978 diatheke (In G. Kittel ed. Theological Dictionary of the New Testament II: 124-6).

14. Arndt, W. F. en F. W. Gingrich. 1974. A Greek-English Lexicon of the New Testament. Chicago : 182.

15. Ibid.

16. Op. cit., 127.

17. Ibid., 126,7 .

18. Burton, E. d. W. 1972 The epistle to the Galatians (ICC). Edinburgh 496-505.

19. Ibid., 496.

20. Ibid., 497,8 .

21. Ibid., 498,9.

22. Ibid., 499, 500.

23. Ibid., 500 .

24. Behm. op. cit., 127.

25. Van Rooy, H. F. 1977. 'n Vergelyking van die struktuur van die buiteBybelse staatsverdrae - met besondere aandag aan die Sefire-verdrae met die struktuur van Deuteronomium. Ongepubliseerde proafskrif: 189192.

26. Vgl. McCarthy, op. cit., 10-34 en 65-73.

27. Van Rooy, 1977, 256-263.

28. Ibid., 70, 71 en $76,77$.

29. McCatthy, D. J. 1963. Treaty and Covenant. Rome: 182-4.

30. Ibid., 198.

31. Weinfeld, M. 1970. "The covenant of grant in the Old Testament." Journal of the Americal Oriental Society, $90: 184-203$.

32. Ibid., 184.

33. Vgl. Van Rooy, 1977, 193-195 vir 'n bespreking hiervan.

34. Lion-Cachet, F. N. 1977. Die kontinuiteit van die Abrahamitiese verbond in die opset van die Sinaïtiese verbond. Ongepubliseerde proefskrif: 151 165 en 167-9.

35. Ibid., 168.

36. Ibid., 163-5.

37. Ibid., 165-6.

38. McCarthy, 1973, 1.

39. Perlitt, L. 1969. Bundestheologie im Alten Testament. Neukirchen. 
40. Vgl. bv. Gerstenberger, E. 1965. "Covenant and commandment". Journal of Biblical Literature, $84: 38-51$; Gese, H. 1967. "Bemerkungen zur Zinaitradition”, ZAW 79: 138, 9; Kutsch in sy gemelde publikasies en Nötscher, F. 1965. "Bundesformular und 'Amtsschimmel'." Biblische Zeitschrift 9: 181. 214.

41. Op. cit., $251-8$.

42. Freedman. D. N. 1964. "Divine commitment and human obligation" Interpretation $18: 429$.

43. Van Rooy, 1977, 251.

44. Ibid., 254, 255, 262, 263.

45. Lion-Cachet, op. cit., 297.

46. Vgl. McCarthy, 1973, 45-52 vir 'n bespreking van die Dawidiese verbond.

47. Van Rooy, 1982, 96.

48. Ibid.

49. Freedman, op. cit., 431.

50. Van Rooy, J. A. 1976. "Verbond of koninkryk". In die Skriflig 10/38 : 6-8.

51. Vgl. Guhrt, op. cit., 369 en Behm, op.cit., 134.

52. op.cit., 370, 1.

53. Behm, op.cit., 129.

54. Burton, op.cit., 301-5.

55. Hendriksen, W. 1974. Colossians and Philemon. Edinburgh: 114-7 en veral in 86 en 87. 